\title{
Study on the Trends of Chronic Kidney Disease and its Management in Owerri, Imo State
}

\author{
Nzeh Nwakaego Evangeline ${ }^{1}$; Chikere Ifeanyi Ebirim ${ }^{1}$; Anabiri Emmanuel Chijindu² ${ }^{2}$ Ori Ebere Chibuzor ${ }^{1}$; Nzeh \\ Ikechukwu Martin ${ }^{3}$; Nzeh Amarachi Frances ${ }^{4}$; Nzeh Chidiebube Paschal'; Mbaegbu Nnamdi Okwudili'; Udo- \\ Inyang Florence ${ }^{7}$; Odupute Colman Ndunaka ${ }^{8}$ and Ede Alison Okorie ${ }^{9}$
}

\author{
${ }^{1}$ Department of Public Health, Federal University of Technology, Owerri \\ ${ }^{2}$ Director African Center for Economic Research and Policy Analysis (ACERPA) and CEO/ MD Alisi \& Sons Nigeria Limited. \\ ${ }^{3}$ Department of Microbiology, Tansian University Oba Anambra State \\ ${ }^{4}$ Department of Medical Laboratory, Madonna University, Okija Campus, Anambra State \\ ${ }^{5}$ Department of Nursing Science, University of Nigeria, Nsukka, Enugu State, Nigeria \\ ${ }^{6}$ Surveillance and Epidemiology Department, Nigeria Centre for Disease Control, Abuja, Nigeria. \\ ${ }^{7}$ Imo State College of Nursing and Midwifery Orlu \\ ${ }^{8}$ Department of Radiology, Kogi State University Teaching Hospital, Dekina, Kogi State, Nigeria \\ ${ }^{9}$ Department of Environmental Health Science, College of Health Sciences and Technology, Nnewi Campus, Nnamdi Azikiwe University, Awka.
}

DOI: 10.29322/IJSRP.12.01.2022.p12151

http://dx.doi.org/10.29322/IJSRP.12.01.2022.p12151

\begin{abstract}
Chronic Kidney Disease (CKD) has been reported as a major cause of death and nephrological disability in adults and it imposes a heavy emotional and financial burden on the family of the affected patient and society. The aim of the study was to determine the incidence of chronic kidney disease among patients in Owerri Zone, Imo State from January 2014 to December 2017. The study design was a retrospective survey on CKD cases and the data were collected from medical record cards with information on incidence rate and risk factors of CKD. The sampling technique adopted for this study was purposive sampling technique because the variables of interest were defined. The collected data were sorted and entered into computer software called Statistical Package for Social Science version 21.0. It was analyzed using descriptive statistical analysis and the results were presented in frequency tables and charts. The results of the study showed the patients with CKD for the period of four years in the studied hospital, the overall prevalence rate of chronic kidney disease (CKD) was 60(9.9\%) and males had 414(67.8\%) while females 197(32.2\%). Majority of the patients with CKD were found to be at the age group of 50-59 years with $217(35.5 \%)$. The cases of CKD were common in year 2016 with 294 cases from month of March to November due high turnout of patients. The most strongly risk factors of CKD was hypertension with 297(48.6\%). There is a significant relationship between the patterns of CKD and age within the study period using Chi-Square test $\left(\mathrm{X}^{2}=44.181\right.$, $\mathrm{p}$-value $=0.001)$. In conclusion, information got from the study was collated and proved significant relationship between risk factors such as hypertension, diabetes, age etc and occurrence of CKD. Therefore, there is a need for free screening of blood pressure and diabetes among people of above forty years of age.
\end{abstract}

Index Terms- Kidney Failure, Hypertension, Patients, Prevalence,

\section{INTRODUCTION}

$\mathrm{C}$ hronic kidney disease (CKD) is a global health burden with a high economic cost to health systems and it is an independent risk factor for cardiovascular disease (CVD) [1]. Chronic kidney disease includes conditions that damage the kidneys and decrease its ability to keep human healthy. If kidney disease gets worse, wastes can build to high levels in the blood and makes an individual feel sick.

A chronic kidney disease can also be regarded as one of the diseases that have threatened mankind and continue to pose a critical health emergency in the global health system. Statistics shows that chronic kidney disease is increasing worldwide by approximately $8-16 \%$ annually $[2,3]$. The incidence of CKD in Nigeria has been shown to be in a range between $1.6 \%$ and $12.4 \%$ respectively. CKD affects male and female, young and aged. It can be acute or chronic. It has been one of the major causes of disability and death in many parts of the world. Chronic kidney disease creates physical impairment as it creates weakness of the body and makes the body unable to carry out its activities. A large budget in America is channeled every year into confronting the global challenge of CKD [4].

According to the hospital based statistics of health and human services statistics of the National Bureau of Statistics [5], $70 \%$ out of $100 \%$ of those diagnosed with chronic kidney disease are young people within the age bracket of 18years to 33years in Imo State and beyond. These individuals constitutes the workforce of Nigeria people, the implication remains that Nigerian Gross Product Development (GPD) continues to dwindle and as such achieving economic development that will accelerate reduction in poverty, unemployment and inequality continues to remain a pious hope. From the idea of researchers, there are risk factors of chronic kidney disease (CKD) such as family history, ethnicity, age and low birth weight. According to American Society of Nephrology [6], it is advised to screen the high-risk family members of those with $\mathrm{CKD}$, in an attempt to prevent any kidney disease. Alper \& 
Batuman, [7] opined that that the lifetime risks of ESRD was 7.8\% for 20 year old black women, $7.3 \%$ for black men, $1.8 \%$ for white women, and $2.5 \%$ for white men. Renal function decreases with age in both men and women. Among the elderly population, more than one-half of the subjects screened had CKD stages 3-5 $\left(\mathrm{GFR}<60 \mathrm{ml} / \mathrm{min}\right.$ per $\left.1.73 \mathrm{~m}^{2}\right)$ according to the National Kidney Foundation Kidney Disease Outcomes Quality Initiative (K/DOQI) guidelines. Therefore, with increase of CKD globally, this study was considered necessary to study on the prevalence of chronic kidney disease among hospitalized patients in Owerri zone hospitals, Imo State

\section{MATERIALS AND METHODS}

This research was carried out among hospitalized patients living with chronic kidney disease in Owerri Zone. The study design was a retrospective survey on CKD cases where the data was collected from medical record unit with information on prevalence rate and risk factors of CKD. The study used all the patients who have presented themselves for Heamodialysis from 2014-2017 at the MTN Foundation Dialysis Center, Federal Medical Center Owerri (FMC).

The population of this study comprised of all the patients who attended Haemodailyis at the MTN Foundation Dialysis Center Federal Medical Center Owerri for the past four years and it was estimated to be 961 .

This study employed a purposive sampling technique in extracting data from MTN Foundation Dialysis from 2014-2017. This is because it is only the hospital that has data on kidney disease patients. All records of CKD from the age of 15 years and above who attended MTN Foundation Dialysis Center at Federal Medical Center Owerri from 2014-2017, were included in the study. The instrument of data collection of this study comprises data collection guide or time series data for secondary data at MTN Foundation Haemodailysis Center at Federal Medical Center Owerri.

The collection of data was done through the reviewed of the medical records of patients from 15 years and above at MTN Foundation Dialysis Center Owerri at the Federal Medical Center Owerri, Imo State. The following data, including age at the time of medical service, hypertension, kidney disease, systemic infection, diabetes mellitus, unhealthy diet, lower urinary tract obstruction and autoimmune diseases, family history, months, years and others were collected.
The data collected were entered into computer software called Statistical package for Social Science (SPSS) version 21.0. It was analyzed using descriptive statistical analysis and the results were presented in frequency tables and charts. Chi-square was used to determine the variables and $95 \%$ confidence intervals (CI) are presented in order to analyze the risk factors related with CKD.

\section{RESULTS}

Table 1 presented the distribution of chronic kidney disease (CKD) among patients attending MTN Foundation Dialysis Centre in Owerri, by age and sex; out of 611 patients assessed through their hospital medical card, $217(35.5 \%)$ of the patients between 50-50 years were diagnosed of CKD, followed by those between 40-49 years with 122(20\%), between 60-69 had $109(17.8 \%)$,between $20-29$ years had $58(9.5 \%)$ while the least was those at less than 20 years with $18(2.9 \%)$.

In regards to sex; $414(67.8 \%)$ of males were diagnosed of CKD while 197 (32.2\%) of females were also diagnosed of CKD over the period from 2014 to 2017.

\section{Table 1: Distribution of CKD among patients attending MTN Foundation Dialysis Centre Owerri, by Age and Sex}

\begin{tabular}{lll}
\hline $\begin{array}{l}\text { Demographic } \\
\text { characteristics }\end{array}$ & $\begin{array}{l}\text { Frequency }(\mathbf{6 1 1}) \\
\text { Age }\end{array}$ & Percentage $(\%)$ \\
<20 years & 18 & \\
20 - 29 years & 58 & 2.9 \\
30 - 39 years & 43 & 9.5 \\
40 - 49 years & 122 & 7.0 \\
50 - 59 years & 217 & 20.0 \\
60 - 69 years & 109 & 35.5 \\
$70+$ years & 44 & 17.8 \\
Sex & & 7.2 \\
Male & 414 & \\
Female & 197 & 67.8 \\
\hline
\end{tabular}

The prevalence of chronic kidney disease (CKD) among hospitalized patients attending MTN Foundation Dialysis Centre Owerri is presented in a pie chart below and only $9.9 \%$ had chronic kidney disease while highest percentage (90.1\%) no chronic kidney disease (figure 1). 


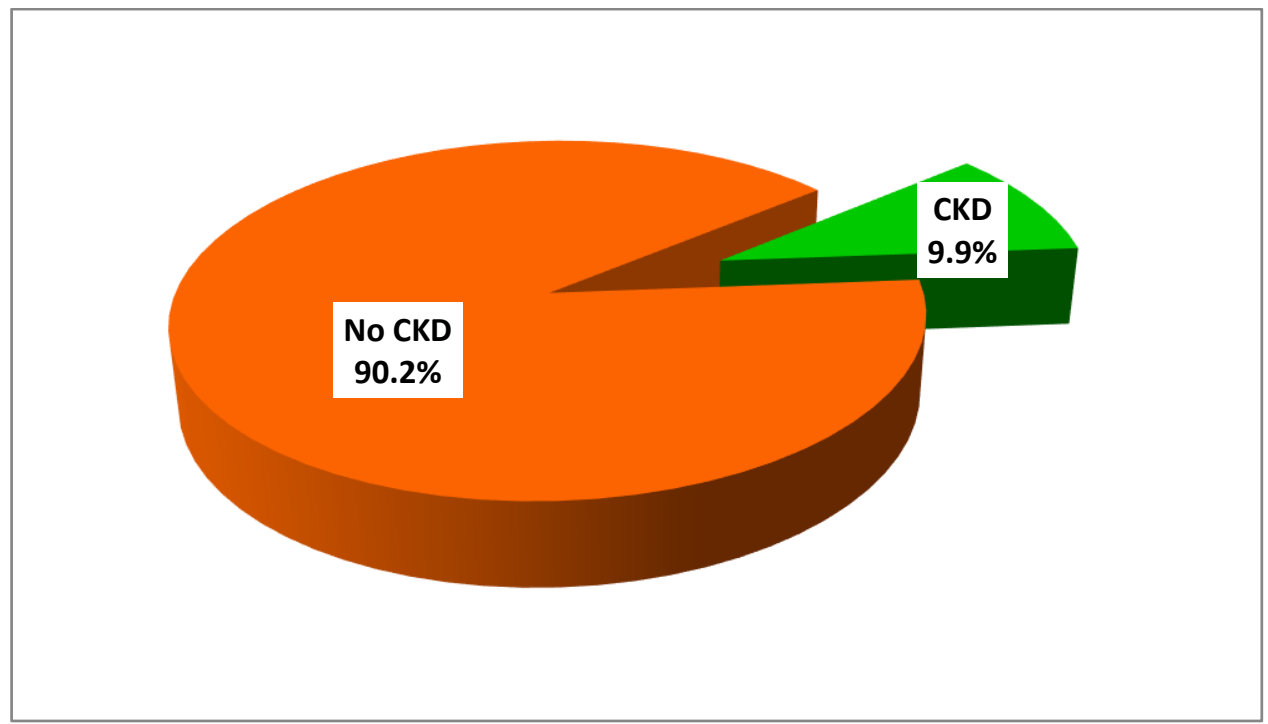

Figure 1: Incidence of Chronic Kidney Disease (CKD)

The table 2 showed the incidence of chronic kidney disease (CKD) by year, hypertensive patients recorded highest in the year 2017 with 263(17.6\%) while the least percent was found in 2015 with 1.8 percent incidence rate.

Table 2: Incidence of Chronic Kidney Disease (CKD) by Year

\begin{tabular}{llll}
\hline Year & $\begin{array}{l}\text { Total number of } \\
\text { hypertensive } \\
\text { patients }\end{array}$ & $\begin{array}{l}\text { Total } \\
\text { number of } \\
\text { CKD cases }\end{array}$ & $\begin{array}{l}\text { Prevalence } \\
\text { rate }\end{array}$ \\
\hline $\mathbf{2 0 1 4}$ & 1215 & 36 & $2.9 \%$ \\
$\mathbf{2 0 1 5}$ & 975 & 18 & $1.8 \%$ \\
$\mathbf{2 0 1 6}$ & 2517 & 294 & $11.7 \%$ \\
$\mathbf{2 0 1 7}$ & 1496 & 263 & $17.6 \%$ \\
\hline
\end{tabular}

\begin{tabular}{llll}
\hline Total & 6203 & 611 & $9.9 \%$
\end{tabular}

The overall incidence of CKD and hypertension as table 3 depicted for four years period from 2014 to 2017, the hypertensive patients were higher in the following months; April with 633(9.5\%) and CKD had 60 cases, August with 580(10\%) and CKD had 58 cases, March recorded 574(11.8\%) and CKD had 68 cases, July recorded 560(14.6\%) and CKD had 82 cases, May recorded 539(13.7\%) and CKD had 74 cases, June recorded 530(13.9\%) and CKD had 74 cases compared to other months while the least was found on February 372(20.2\%) and CKD had 75 cases.

Table 3: Trend of CKD and hypertension by Months

\begin{tabular}{|c|c|c|c|}
\hline Year & $\begin{array}{l}\text { Total number of hypertensive } \\
\text { patients }\end{array}$ & $\begin{array}{l}\text { Total number of CKD } \\
\text { cases }\end{array}$ & Incidence rate \\
\hline January & 427 & 28 & $6.6 \%$ \\
\hline February & 372 & 75 & $20.2 \%$ \\
\hline March & 574 & 68 & $11.8 \%$ \\
\hline April & 633 & 60 & $9.5 \%$ \\
\hline May & 539 & 74 & $13.7 \%$ \\
\hline June & 530 & 74 & $13.9 \%$ \\
\hline July & 560 & 82 & $14.6 \%$ \\
\hline August & 580 & 58 & $10.0 \%$ \\
\hline
\end{tabular}




\begin{tabular}{llll}
\hline September & 488 & 13 & $2.7 \%$ \\
October & 502 & 28 & $5.6 \%$ \\
November & 514 & 26 & $5.1 \%$ \\
December & 484 & 25 & $5.2 \%$ \\
Total & $\mathbf{6 2 0 3}$ & $\mathbf{6 1 1}$ & $9.9 \%$ \\
\hline
\end{tabular}

Table 4 showed that the overall cases of CKD by months and years; the highest $82(13.4 \%)$ was seen in July for four years period (2014-2017) while the least was found on September with $13(2.1 \%)$.

In 2014; February recorded highest cases of CKD with $9(25 \%)$ followed by May with $8(22.2 \%)$ and the least was on September and November with 1(2.8\%).
In 2015; March and April recorded highest cases of CKD with 6(33.3\%) followed by May with 3(16.7\%) and the least was on February, October and November with 1(5.6\%).

In 2016; August recorded highest cases of CKD with $58(19.7 \%)$ followed by July with $46(15.6 \%)$ and the least was on April with $9(3.1 \%)$.

In 2017; May recorded highest cases of CKD with $53(20.2 \%)$ followed by June with 51(19.4\%) and the least was on January with $8(3 \%)$.

Table 4: Trend of CKD by Monthly and Year

\begin{tabular}{llllll}
\hline Month & $\begin{array}{l}\mathbf{2 0 1 4} \\
\mathbf{n}(\boldsymbol{\%})\end{array}$ & $\begin{array}{l}\mathbf{2 0 1 5} \\
\mathbf{n}(\boldsymbol{\%})\end{array}$ & $\begin{array}{l}\mathbf{2 0 1 6} \\
\mathbf{n}(\boldsymbol{\%})\end{array}$ & $\begin{array}{l}\mathbf{2 0 1 7} \\
\mathbf{n}(\boldsymbol{\%})\end{array}$ & $\begin{array}{l}\text { Total } \\
\mathbf{n}(\boldsymbol{\%})\end{array}$ \\
\hline January & $7(19.4)$ & 0 & $13(4.4)$ & $8(3.0)$ & $28(4.6)$ \\
February & $9(25.0)$ & $1(5.6)$ & $29(9.9)$ & $36(13.7)$ & $75(12.3)$ \\
March & 0 & $6(33.3)$ & $22(7.5)$ & $40(15.2)$ & $68(11.1)$ \\
April & 0 & $6(33.3)$ & $9(3.1)$ & $45(17.1)$ & $60(9.8)$ \\
May & $8(22.2)$ & $3(16.7)$ & $10(3.4)$ & $53(20.2)$ & $74(12.1)$ \\
June & $2(5.6)$ & 0 & $21(7.1)$ & $51(19.4)$ & $74(12.1)$ \\
July & $6(16.7)$ & 0 & $46(15.6)$ & $30(11.4)$ & $82(13.4)$ \\
August & 0 & 0 & $58(19.7)$ & 0 & $58(9.5)$ \\
September & $1(2.8)$ & 0 & $12(4.1)$ & 0 & $13(2.1)$ \\
October & $2(5.6)$ & $1(5.6)$ & $25(8.5)$ & 0 & $28(4.6)$ \\
November & $1(2.8)$ & $1(5.6)$ & $24(8.2)$ & 0 & $26(4.3)$ \\
$\begin{array}{l}\text { December } \\
\text { Total }\end{array}$ & 0 & 0 & $25(8.5)$ & 0 & $25(4.1)$ \\
\hline
\end{tabular}

\section{Chi-square $=293.977$, p-value $<0.001$}

Figure 2 presented the factors affecting the hypertension and CKD in the studied centers; $7.3 \%$ of the patients' reported excess alcohol; $48.6 \%$ reported high blood pressure influences CKD occurrence, 5\% reported systemic infection, diabetes mellitus recorded $16.3 \%$, unhealthy diet recorded $7.4 \%$, age has $8.6 \%$, lower urinary tract obstruction and autoimmune diseases had $1.3 \%$ each; family history has $3.4 \%$ and others were $0.5 \%$. 


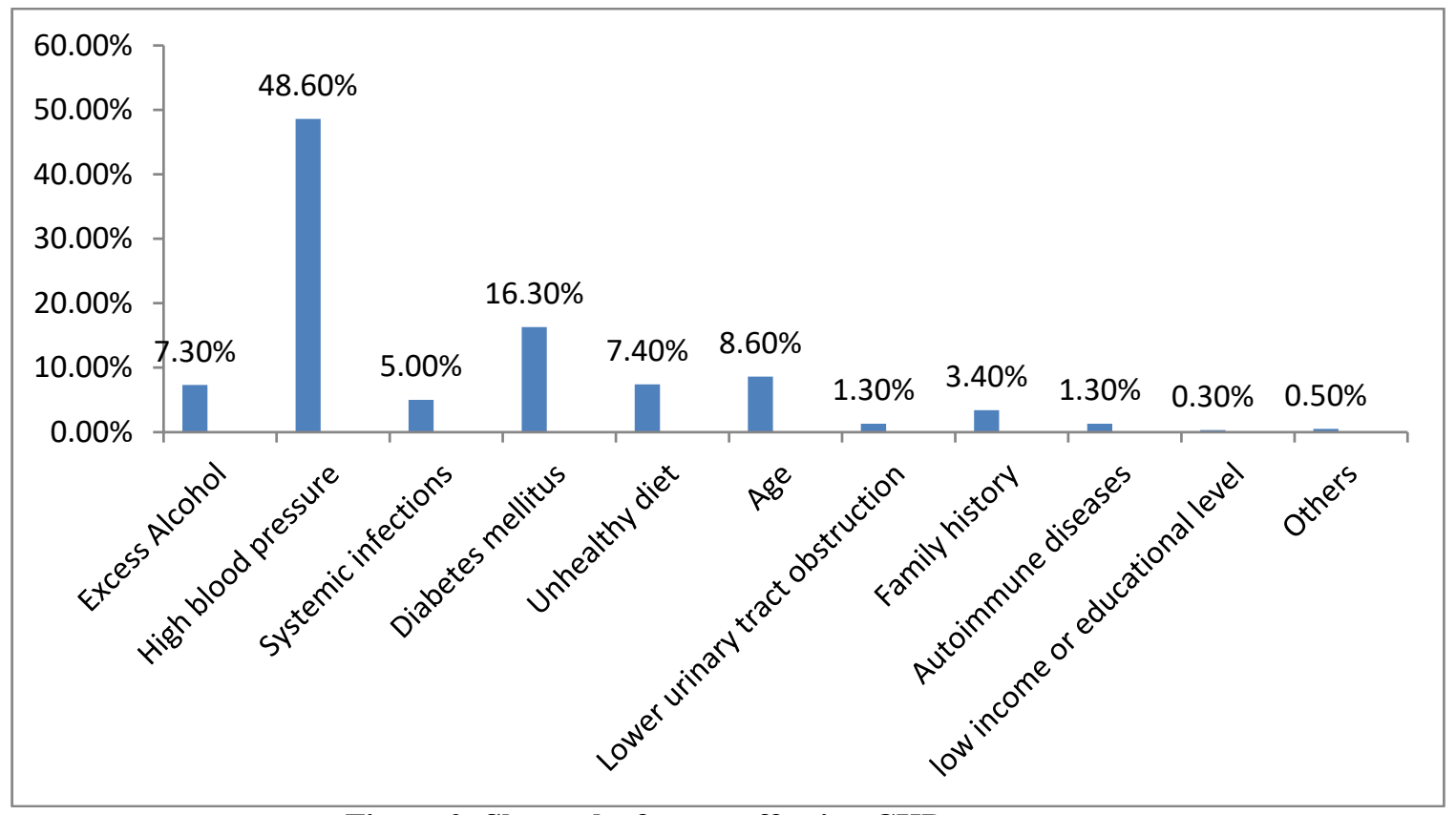

Figure 2: Shows the factors affecting CKD occurrence

Table 5 presented the management strategies of hypertension; 175(28.6\%) applied lisinopril, dialysis, iron succrose, normal saline, 127(42.1\%) applied amilodipine, dialysis, iron succrose, normal saline, 103(16.9\%) applied glucophage, dialysis, iron succrose, normal saline, 18(2.9\%) applied prosca, dialysis, iron succrose, normal saline, 42(6.8\%) applied norvase, dialysis, iron succrose, normal saline and 11(1.8\%) applied adomet, dialysis, iron succrose, normal saline.

Table 5: Management of CKD

\begin{tabular}{llll}
\hline Management of CKD & & Frequency & $\begin{array}{l}\text { Percentage } \\
(\%)\end{array}$ \\
\hline $\begin{array}{l}\text { Lisinopril, dialysis, } \\
\text { succrose, normal saline }\end{array}$ & iron & 175 & 28.6 \\
$\begin{array}{l}\text { Amilodipine, dialysis, } \\
\text { succrose, normal saline }\end{array}$ & 257 & 42.1 \\
$\begin{array}{l}\text { Glucophage, dialysis, iron } \\
\text { succrose, normal saline }\end{array}$ & 103 & 16.9 \\
\hline
\end{tabular}

\begin{tabular}{|c|c|c|}
\hline $\begin{array}{l}\text { Prosca, } \begin{array}{l}\text { dialysis, } \\
\text { succrose, normal saline }\end{array} \\
\end{array}$ & 18 & 2.9 \\
\hline $\begin{array}{l}\text { Haemoglobine } 12 \text {, dialysis, } \\
\text { iron succrose, normal saline }\end{array}$ & 5 & 0.8 \\
\hline $\begin{array}{l}\text { Norvase, dialysis, iron } \\
\text { succrose, normal saline }\end{array}$ & 42 & 6.8 \\
\hline $\begin{array}{l}\text { Adomet, dialysis, iron } \\
\text { succrose, normal saline }\end{array}$ & 11 & 1.8 \\
\hline Total & 611 & 100.0 \\
\hline
\end{tabular}

\section{Authors Computation}

The figure 3 below presented the distribution of CKD by gender for the period of four years in the studied hospitals. In 2014, male has $38.9 \%$ while female has $61.1 \%$. In $2015,77.8 \%$ were for male while $22.2 \%$ were for female. In 2016, $78.9 \%$ were for male while $21.1 \%$ for female. In 2017 , males had $58.6 \%$ while females had $41.4 \%$. 


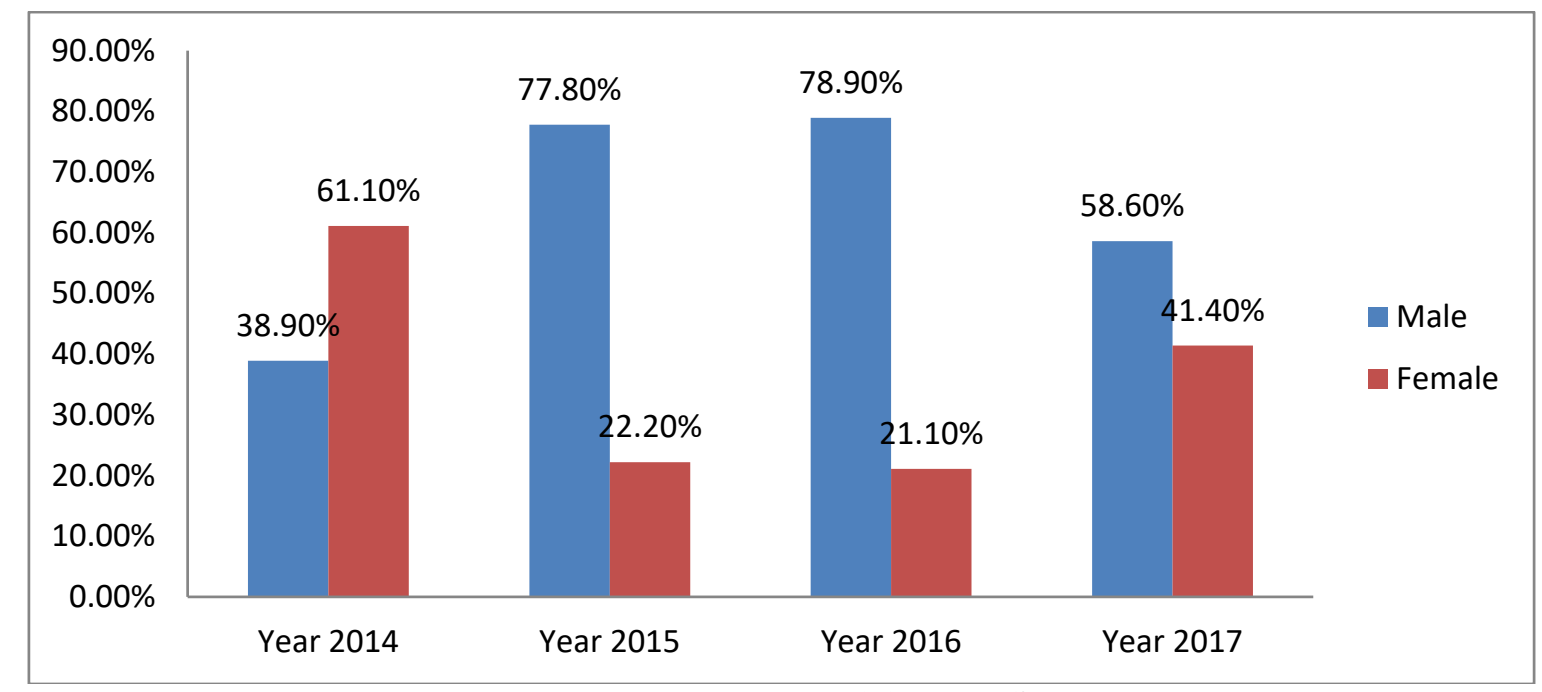

Figure 3: Distribution of CKD by Sex

Chi-square $=41.498$, p-value $<0.001$

Table 6 presented the overall cases of CKD by age and year were recorded highest with $217(35.5 \%)$ between 50-59 years for period of four years from 2014-2017 while the least was found on September with $18(2.9 \%)$ in those less than 20 years.

In 2014; between 50-59 years recorded highest with $22(61.1 \%)$ followed by 40-49 years and 60-69 years with $4(11.1 \%)$ and the least was on above 70 years with $1(2.8 \%)$ cases of CKD.

In 2015; between 50-59 years recorded highest with $7(38.9 \%)$ followed by $40-49$ years and 60-69 years with $4(22.2 \%)$ and the least was between $30-39$ years with $1(5.6 \%)$ cases of CKD.

In 2016; between 50-59 years recorded highest with $96(32.7 \%)$ followed by $60-69$ years with $54(18.4 \%)$ and the least was on less than 20 years with $14(4.8 \%)$ cases of CKD.

In 2017; between 50-59 years recorded highest with $92(35 \%)$ followed by $40-49$ years with $72(27.4 \%)$ and the least was on less than 20 years with $4(1.5 \%)$ cases of CKD.

Table 6: Trend of CKD by Age and Year

\begin{tabular}{|c|c|c|c|c|c|}
\hline $\begin{array}{l}\text { Age } \\
\text { group }\end{array}$ & $\begin{array}{l}2014 \\
\text { n }(\%)\end{array}$ & $\begin{array}{l}2015 \\
\text { n }(\%)\end{array}$ & $\begin{array}{l}2016 \\
\text { n }(\%)\end{array}$ & $\begin{array}{l}2017 \\
\text { n }(\%)\end{array}$ & $\begin{array}{l}\text { Total } \\
\text { n }(\%)\end{array}$ \\
\hline$<20$ & 0 & 0 & $\begin{array}{l}14 \\
(4.8)\end{array}$ & $4(1.5)$ & $\begin{array}{l}18 \\
(2.9)\end{array}$ \\
\hline
\end{tabular}

\begin{tabular}{|c|c|c|c|c|c|c|}
\hline $\begin{array}{l}20 \\
29\end{array}$ & - & $3(8.3)$ & 0 & $\begin{array}{l}41 \\
(13.9)\end{array}$ & $\begin{array}{l}14 \\
(5.3)\end{array}$ & $\begin{array}{l}58 \\
(9.5)\end{array}$ \\
\hline $\begin{array}{l}30 \\
39\end{array}$ & - & $2(5.6)$ & $1(5.6)$ & $\begin{array}{l}22 \\
(7.5)\end{array}$ & $\begin{array}{l}18 \\
(6.8)\end{array}$ & $\begin{array}{l}43 \\
(70)\end{array}$ \\
\hline $\begin{array}{l}40 \\
49\end{array}$ & - & $4(11.1)$ & $4(22.2)$ & $\begin{array}{l}42 \\
(14.3)\end{array}$ & $\begin{array}{l}72 \\
(27.4)\end{array}$ & $\begin{array}{l}122 \\
(20.0)\end{array}$ \\
\hline $\begin{array}{l}50 \\
59\end{array}$ & - & $22(61.1)$ & $7(38.9)$ & $\begin{array}{l}96 \\
(32.7)\end{array}$ & $\begin{array}{l}92 \\
(35.0)\end{array}$ & $\begin{array}{l}217 \\
(35.5)\end{array}$ \\
\hline $\begin{array}{l}60 \\
69\end{array}$ & - & $4(11.1)$ & $4(22.2)$ & $\begin{array}{l}54 \\
(18.4)\end{array}$ & $\begin{array}{l}47 \\
(17.9)\end{array}$ & $\begin{array}{l}109 \\
(17.8)\end{array}$ \\
\hline 70+ & & $1(2.8)$ & $2(11.1)$ & $\begin{array}{l}25 \\
(8.5)\end{array}$ & $\begin{array}{l}16 \\
(6.1)\end{array}$ & $\begin{array}{l}44 \\
(7.2)\end{array}$ \\
\hline Total & & $36(100.0)$ & $18(100.0)$ & $\begin{array}{l}294 \\
(100.0)\end{array}$ & $\begin{array}{l}25 \\
(100.0)\end{array}$ & $\begin{array}{l}611 \\
(100.0)\end{array}$ \\
\hline
\end{tabular}

Chi-square $=44.181, p$-value $=0.001$

The figure 4 below presented the gender distribution of CKD among patients for the period of four years in the studied hospitals. Majority 151(69.6\%) were male between $50-59$ years while female has $66(30.4 \%)$. In all the age group, the lowest was on those less than 20 years with $10(55.6 \%)$ for male and $8(44.4 \%)$ for female. 


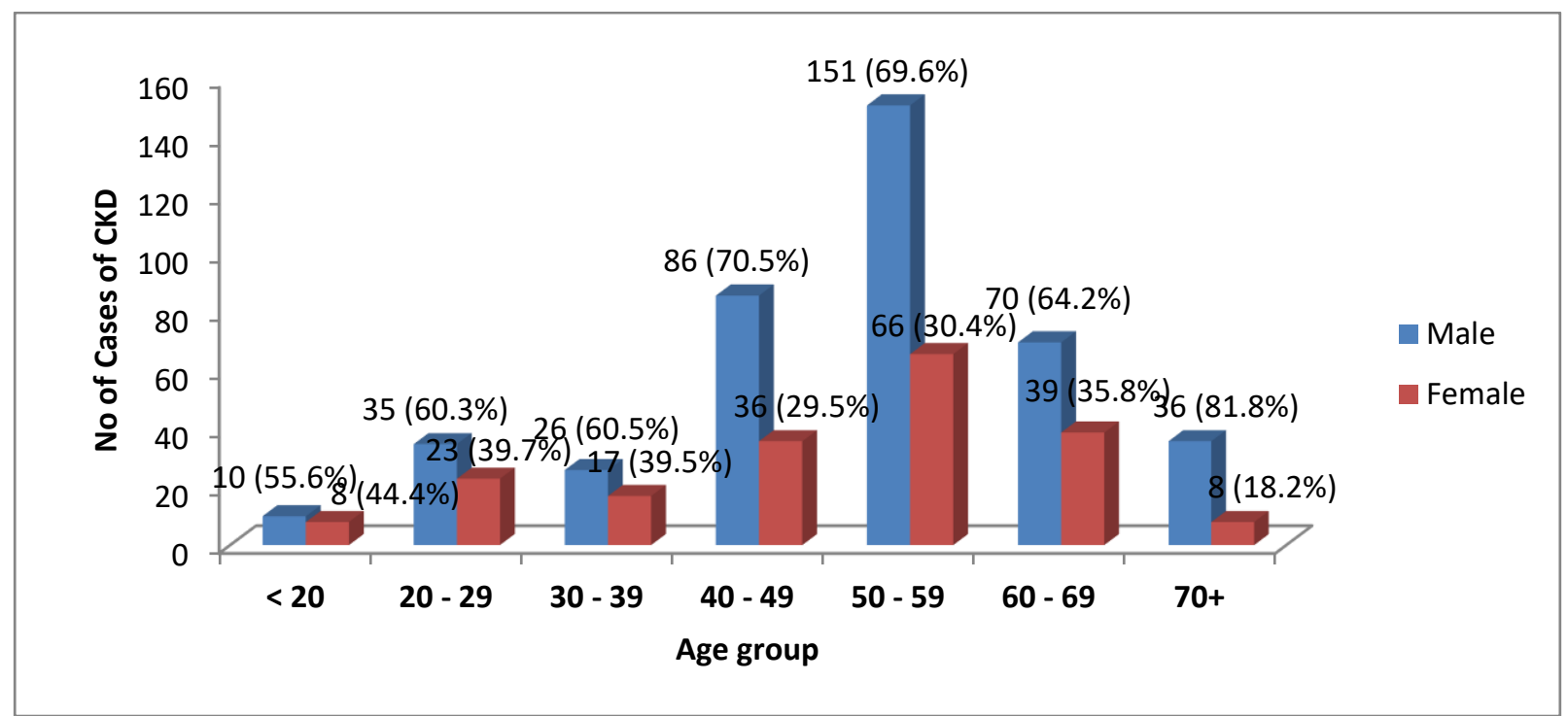

\section{Figure 3: Distribution of CKD by Age Chi-square $=9.088$, $p$-value $=0.169$}

\section{DISCUSSION}

The findings from a retrospective survey on time trend in the epidemiology of chronic kidney disease in Foundation Dialysis Centre in Owerri, Imo State from January 2014 to December 2017; showed that $9.9 \%$ had chronic kidney disease and it was similar to the result gotten from Egbi et al. [1] among Civil Servants in Bayelsa State using survey research and they found that the prevalence of chronic kidney disease in the study was $7.8 \%$, prevalence rate $(14.6 \%)$ of hypertension was high in month of July and some risk factors for chronic diseases are excess alcohol, tobacco smoking, inadequate physical activity, high salt intake, unhealthy diet, age, obesity, family history and abnormal blood lipids are highly responsible for the occurrence of chronic kidney disease. Although chronic kidney disease (CKD) cases are increasing globally, incidence of the disease in Nigeria is more pathetic as experts say it is largely caused by preventable risk factors as mentioned earlier and lack of proper health care facilities [1].

According to Boris [8], stated that one million deaths worldwide resulted from CKD and it remains among the few growing causes of mortality which made chronic kidney disease the $13^{\text {th }}$ leading cause of death [8]. All increase in CKD as observed in some studies such as in Taiwan, CKD was 6.9\% [9], in Teaching Hospital in South-East Nigeria, CKD was [10]. The studies proved that increase in prevalence of CKD was due to low awareness on the risk factors of CKD.

In relation to the causes of chronic kidney disease, diabetes and hypertension are the first two leading causes of CKD. In the Western world, diabetes is the leading cause, whereas in many undeveloped countries it is hypertension and the findings showed high cases of hypertension. According to Agboton, [11], family history, high blood pressure, diabetes mellitus, autoimmune diseases, systemic infections, urinary tract infections, urinary stones, lower urinary tract obstruction, low income or educational level etc are progression factors that can $10 \%$ cases of chronic renal failure.
Following the reported Ministry of Health and Kidney Health of New Zealand in [12], there is convincing evidence that good control of blood sugar levels and blood pressure can reduce or, in some cases, prevent progressive kidney damage among people which was similar to the observed factors in this study. After the exclusion of patients with cardiovascular problem due to hereditary disorders and urologic causes, nearly $23 \%$ of incident dialysis patients had close relatives with CKD and in line with this result. Hence, it is advised to screen the high-risk family members of those with CKD, in an attempt to prevent any kidney disease [7].

Many studies have demonstrated that CKD is more frequent among men compared to women. In one study, a total of 107,192 subjects over 18 years of age (51,122 men and 56,070 women) from Okinawa, Japan participated in a 10-year follow-up where odds ratio for CKD was 1.41 among male participants. In contrast, on another study demonstrated that CKD is higher in women than in men (18.4 vs $12.8 \%)$ in Turkey but in this study, greater percentage $(67.8 \%)$ was for men compared to women with $32.2 \%$ [13].

In terms of management aspect of CKD, blood pressure drugs or anti-hypertensives are medications designed to lower blood pressure. Untreated high blood pressure can cause permanent damage to the small arteries of the kidneys, as well as to the heart and the brain. From the findings of this study; the major management practice in prevention of CKD was with the application of amilodipine, dialysis, iron succrose, normal saline followed by lisinopril, dialysis, iron succrose, normal saline. The reason could that, they are commonly available to patient and perform good efficacy on patients.

\section{CONCLUSION}

The base line information got from the study was collated and analyzed and it showed that there a significant relationship between risk factors such as age, family history, high blood pressure, diabetes mellitus, autoimmune diseases, systemic 
infections, urinary tract infections, urinary stones, lower urinary tract obstruction etc and occurrence of CKD. Therefore, time trend in the epidemiology of CKD in Imo State was high in men compared to women counterpart in regard to CKD admissions and prevalence from the assessed medical recorded in the hospitals.

\section{RECOMMENDATIONS}

Based on the findings of the study, the following recommendations were necessary such as;

1. They should encourage free screening of blood pressure and sugar level on people of above forty years of age

2. They should be awareness on the risk factors that can lead to the occurrence of CKD.

3. Government should empower health workers at local level on the equipment for screening of people that are at risk of developing CKD

4. Heavy drinkers and smokers should be encouraged to reduce it in order to avoid the cases of CKD.

\section{REFERENCES}

[1] Egbi, O.G., Okafor, U. H., Kasia, B. E. Olowu, O. E. Unuigbe, E. I. (2014). Prevalence and correlates of chronic kidney disease among civil servants in Bayelsa State, Nigeria. Niger Journal Clinical Practice. 17:602-7.

[2] Anderson, J. \& Glynn, L.G. (2011).Definition of chronic kidney disease and measurement of kidney function in original research papers: A review of th e literature. Nephrology Dialysis Transplantation, 26(9):1-8.

[3] Arnold, R, Issar,T., Krishnan, A.V \& Pussell, B.A. (2016).Neurological complications in chronic kidney disease. Sage Publishers.

[4] Abraham, G.A., Gopalakrishnan, K.N., Renuka, N., Pahari, S., Deshpandel, D.K. \& Isaac, R. P (2017). Management of hypertension in chronic kidney disease: Consensus statement by an expert panel of Indian Nephrologists. $J$ ournal of Association of Physicians India; 65(2):6-12

[5] National Bureau of Statistics (NBS, 2016). Data statistical analysis guide for coping with chronic kidney disease in Nigeria

[6] American Society of Nephrology (2010): CIASN:5(1) PubMed center

[7] Alper, A.B. \& Batuman, V. (2017).Tubulo-interstitial nephritis. Medscape Medical News.

[8] Boris, B. (2015). Chronic kidney disease: Impact on the global burden of mortality and morbidity. Lancet; 2-3.

[9] Hsu, C.C., Hwang, S.J., Wen, C.P., Chang, H.Y., Chen, T., Shiu, R.S., \& Yang, W.C. (2006). American Journal of Kidney Disease. 2006; 48(5):727. International Society of Nephrology's Kidney Disease Data Center (ISN$\mathrm{KDDC})$
[10] Ulasi, I.I. \& Ijeoma, C.K., (2010).The enormity of chronic kidney disease in Nigeria: The situation in a teaching hospital in South-East Nigeria. Journal of Tropical Medicine 77-81

[11] Agboton, B.L. (2017). Hypertensive and diabetic history of patients on chronic dialysis prior to chronic kidney disease stage in Benin. Journal of Kidney; 3:150.

[12] Ministry of Health and Kidney Health New Zealand. (2014). Living with Kidney Disease: A comprehensive guide for coping with chronic kidney disease. Second edition. Wellington: Ministry of Health.

[13] . Kazancioğlu, R. (2011). Risk factors for chronic kidney disease: an update. Kidney International Supplement; 3(4): 368-371.

\section{AUTHORS}

First Author - Nzeh Nwakaego Evangeline, Department of Public Health, Federal University of Technology, Owerri

Second Author - Chikere Ifeanyi Ebirim, Department of Public Health, Federal University of Technology, Owerri

Third Author - Anabiri Emmanuel Chijindu, Director African Center for Economic Research and Policy Analysis (ACERPA) and CEO/ MD Alisi \& Sons Nigeria Limited.

Fourth Author - Ori Ebere Chibuzor, Department of Public Health, Federal University of Technology, Owerri Fifth Author - Nzeh Ikechukwu Martin, Department of Microbiology, Tansian University Oba Anambra State

Sixth Author - Nzeh Amarachi Frances, Department of Medical Laboratory, Madonna University, Okija Campus, Anambra State Seventh Author - Nzeh Chidiebube Paschal, Department of Nursing Science, University of Nigeria, Nsukka, Enugu State, Nigeria

Eight Author - Mbaegbu Nnamdi Okwudili, Surveillance and Epidemiology Department, Nigeria Centre for Disease Control, Abuja, Nigeria.

Ninth Author - Udo-Inyang Florence, Imo State College of Nursing and Midwifery Orlu

Tenth Author - Odupute Colman Ndunaka, Department of Radiology, Kogi State University Teaching Hospital, Dekina, Kogi State, Nigeria

Eleventh Author - Ede Alison Okorie, Department of Environmental Health Science, College of Health Sciences and Technology, Nnewi Campus, Nnamdi Azikiwe University, Awka.

Corresponding Author: Ede.A.O edeokorie@mail.com 